\title{
STORY TELLING MENGGUNAKAN MEDIA GAMBAR BERBASIS PENGETAHUAN LOKAL MADURA SEBAGAI STRATEGI DALAM BERBICARA SISWA KELAS VII SMP
}

\author{
Siti Mutiatun \\ Universitas Trunojoyo Madura \\ Email: siti.mutiatun@trunojoyo.ac.id
}

\begin{abstract}
One of the four language skills is speaking. Speaking is one of the skills used to communicate directly. In contrast to other skills, speaking is one of the skills that is difficult to be applied due to the introvert and extrovert factors in each child. Story telling is a retelling activity of a story that is packed with local Madura knowledge. With stories based on local Madura knowledge, students retell according to their understanding. This research is a qualitative descriptive study that will describe the students' speaking activities. This study also describes efforts to optimize stor telling as a strategy that students are interested in using stories based on local Madura knowledge.
\end{abstract}

Keywords: Storytelling, Madura local knowledge-Based Picture, Speaking Strategy

\begin{abstract}
Abstrak
Empat keterampilan dalam berbahasa salah satunya adalah berbicara. Berbicara merupakan salah satu keterampilan yang digunakan untuk berkomunikasi secara langsung. Berbeda dengan keterampilan lainnya, berbicara adalah salah satu keterampilan yang sulit diterapkan dikarenakan adanya faktor introvert dan extrovert pada setiap anak. Story telling merupakan kegiatan menceritakan ulang dari sebuah cerita yang dikemas dengan pengetahuan lokal madura. Dengan cerita berbasis pengetahuan lokal Madura siswa menceritakan kembali sesuai dengan pemahamannya. Penelitian ini merupakan penelitian deskriptif kualitatif yang akan mendeskripsikan tentang kegiatan berbicara siswa. Penelitian ini juga mendeskripsikan tentang usaha mengoptimalkan story telling sebagai strategi yang diminati siswa dengan menggunakan cerita-cerita yang berbasis pengetahuan lokal Madura.
\end{abstract}

Kata Kunci: Storytelling, Gambar Berbasis Pengetahuan Lokal Madura, Strategi Berbicara

\section{PENDAHULUAN}

Bahasa adalah satu-satunya alat komunikasi yang pertama yang paling dibutuhkan oleh setiap orang. Dengan adanya bahasa maka komunikasi antar satu dengan yang lainnya akan terjalin dengan baik. Setiap manusia yang lahir, mereka akan mengenal dan belajar bahasa sebagai awal komunikasinya. Namun, meskipun bahasa telah diajarkan mulai anak masih kecil, nyatanya belajar bahasa bukanlah hal yang mudah. Terdapat empat keterampilan dalam bahasa diantaranya adalah berbicara. Berbicara merupakan salah satu keterampilan yang digunakan sebagai alat komunikasi langsung. Sebagai alat komunikasi tentunya berbicara berhubungan erat dengan kekayaan dan perkembangan kosa kata yang akan digunakan dalam pengaplikasiannya.

Story telling merupakan cara melatih berbahasa dengan mengasah banyak kosa kata yang nantinya akan dirangkai menjadi deretan kalimat. Penampilan siswa dalam story telling juga berpengaruh kepada kepercayaan dirinya sehingga dengan sering melakukannya siswa akan terus mengasah kepercayaan dirinya sambil mengasah kosa katanya. Dengan demikian anak akan lancar dalam berbahasa dan mengomunikasikan bahasanya. Hal ini dinilai sangat baik diterapkan untuk pemebelajaran bahasa pada keterampilan berbicara.

Gambar merupakan alat bantu yang digunakan untuk melakukan story telling khususnya dalam menemukan kosa kata yang akan dikumpulkan siswa. Dengan bantuan gambar siswa bisa menulis kosa kata yang telah ditemukan yang kemudian bisa dirangkai dalam bentuk kalimat yang baik dan benar serta bisa dikomunikasikan di hadapan teman-temannya. Dengan adanyanya bantuan gambar siswa juga 
bisa mengekspresikan kalimatnya sesuai dengan apa yang mereka lihat.

Penyajian gambar berbasis pengetahuan lokal Madura merupakan cara yang memudahkan mereka berpikir. Pengetahuan yang sesuai dengan lokal mereka memberi pandangan sehingga dengan mudah menalar dan membatasi gagasannya. Penyajian gambar berbasis pengetahuan lokal Madura ditujukan agar siswa mudah mengenal sesuai dengan karakter yang ada di Madura. Sehingga dengan adanya gambar berkearifan lokal Madura siswa bisa langsung menangkap adanya gambar tersebut

\section{KAJIAN TEORI \\ Story Telling}

Story telling merupakan frase yang terdiri dari dua kata yaitu story (cerita) dan telling (Penceritaan). Sederhananya, pengertian dari story telling adalah kegiatan menyampaikan cerita. Seseorang yang melakukan story telling disebut dengan pencerita atau pendongeng. Secara tradisional, story telling dilakukan secara lisan. Akan tetapi, seiring perjalanan waktu, story telling juga bisa dilakukan dengan bantuan beberapa alat dan media. Seperti misalnya: penulis yang menggunakan media kertas atau buku atau bahkan blog untuk menuangkan ceritanya, musisi yang menggunakan lagu untuk bercerita, bahkan para designer yang menggunakan media pakaian untuk bercerita. Dalam konteks pembelajaran, story telling bdapat digunakan para guru dalam metode belajar khususnya belajar berbahasa. Dengan menggunakan media belajar story telling diharapkan agar siswa lebih mudah memahami materi.

Adapun fungsi dari story telling adalah: 1) Mengasah kemampuan berbicara dan mendengarkan dalam Bahasa Inggris. 2) Melatih pronunciation (pelafalan). 3) Menambah pembendaharaan kosakata, frasa, dan idiom bahasa Inggris. 4) Meningkatkan kepercayaan diri dalam menggunakan berbahasa. 5) Memungkinkan anak-anak mempelajari budaya negara lain, apalagi jika storyteller seorang native speaker.

\section{Media Gambar Berbasis Pengetahuan lokal Madura}

Pengertian media berasal dari bahasa latin yaitu medium yang berarti secara harfiah perantara atau pengirim pesan. Terdapat beberapa pengertian media menurut para ahli, yakni menurut Ahmad Rohani, media adalah segala sesuatu yang dapat di indera yang berfungsi sebagai perantara atau sarana untuk proses komunikasi proses belajar mengajar. Menurut Santoso S. Hamijaya, media adalah semua bentuk perantara yang dipakai orang penyebar ide, sehingga ide atau gagasan itu sampai pada penerima. Pengertian gambar menurut Oemar Hamalik (1986:43), gambar adalah segala sesuatu yang diwujudkan secara visual dalam bentuk dua dimensi sebagai curahan perasaan atau pikiran. Sedangkan menurut KBBI, gambar adalah tiruan barang, binatang, tumbuhan dan sebagainya.

Berdasarkan penjelasan di atas, dapat diambil kesimpulan dari pengertian media gambar adalah suatu bentuk visual yang hanya dapat dilihat, namun tidak memiliki unsur suara atau audio. Pengertian media gambar yang lain, media gambar adalah segala sesuatu yang bisa diwujudkan secara visual dua dimensi sebagai pemikiran atau curahan yang bermacammacam. Terdpaat satu istilah lagi yang disebut dengan media gambar berseri. Sedangkan pengertian media gambar seri yaitu suatu urutan gambar yang mengikuti percakapan guna menggambarkan arti yang ada dalam gambar. Disebut dengan gambar seri, karena gambar yang satu dengan yang lain saling berkaitan.

Media gambar yang dijelaskan di atas memiliki fungsi dalam proses belajar pembelajaran. Adapun fungsi media gambar yaitu sebagai alat bantu dalam kegiatan belajar. Fungsi lain dari media bergambar adalah memberikan pengalaman visual pada anak guna mendorong motivasi belajar dan mempermudah konsep yang kompleks dan abstrak menjadi lebih sederhana, konkret dan mudah dipahami. Secara spesifik fungsi media gambar dalam proses pembelajaran, antara lain:

1) Fungsi Atensi

Media visual atau gambar memiliki peran untuk menarik dan mengarahkan perhatian siswa untuk berkonsentrasi pada isi pelajaran. Dengan demikian fungsi atensi berkaitan dengan makna visual yang ditampilkan atau yang menyertai teks materi pelajaran.

2) Fungsi Afektif

Media visual atau gambar dapat terlihat dari tingkat kenikmatan siswa saat belajar atau membaca teks yang bergambar.

3) Fungsi Kognitif 
Fungsi kognitif berarti media visual atau gambar terlihat dari cara mengungkapkan bahwa lambang visual atau gambar memperlancar pencapaian tujuan untuk memahami dan mengingat informasi atau pesan yang terkandung dalam gambar.

4) Fungsi Kompensatoris

Fungsi terakhir adalah kompensatoris, menurut hasil penelitian bahwa media visual atau gambar memberikan konteks untuk memahami teks membantu siswa yang lemah dalam membaca. Fungsi lain untuk mengorganisasikan informasi dalam teks dan mengingatnya kembali. Dengan arti lain, media pembelajaran berfungsi untuk mengakomodasi siswa yang lemah dan lambat menerima dan memahami isi pelajaran yang disajikan dengan teks atau disajikan secara verbal.

Manfaat media gambar berdasarkan fungsi yang telah dijelaskan di atas menurut Subana (1998:322) manfaat gambar sebagai media pembelajaran yaitu: meningkatkan daya tarik siswa, mempermudah pengertian atau pemahaman siswa, mempermudah pemahaman yang sifatnya abstrak, memperjelas dan memperbesar bagian yang penting atau bagian kecil sehingga dapat diamati, dan menyingkat suatu uraian.

Dari uraian definisi serta fungsi media gambar di atas, kemudian muncul media gambar yang disesuaikan dengan pengetahuan lokal Madura. Media gambar berbasis pengetahuan lokal Madura adalah gambar yang yang disajikan dengan cerita-cerita Madura. Menurut Koentjaraningrat dalam $\mathrm{H}$. Hartono ada tiga wujud budaya yang terdapat dalam pengetahuan lokal. Salah satunya adalah wujud hasil karya manusia yang bisa dilihat, diraba dan difoto. Dalam wujud inilah kemudian media gambar berbasis pengetahuan lokal Madura menjadi lebih mudah disajikan. Sesuai dengan yang diungkapkan Subana (1998:322) salah satu fungsi dari media gambar adalah mempermudah pengertian dan pemahaman siswa. Sehingga dengan gambar yang berbasis pengetahuan lokal Madura siswa akan lebih memahami yang nantinya akan berpengaruh pada gagasan yang diungkapkan dalam bercerita.

\section{Berbicara}

Berbicara adalah salah satu keterampilan dalam berbahasa. Menurut Kamus Besar Bahasa Indonesia (2001) keterampilan adalah kecakapan untuk menyelesaikan tugas. Dalam hal ini berarti keterampilan berbicara adalah kecakapan siswa dalam berbicara. Sementara menurut Brown and Yule dalam Suwarti berbicara adalah kemampuan dalam mengucapkan bunyi-bunyi bahasa untuk mengekspresikan dan menyampaikan pikiran atau gagasan secara lisan. Merujuk pada definisi tersebut, siswa dalam hal ini melakukan komunikasi secara langsung karena dilakukan dengan bahasa lisan. Definisi tersebut sesuai dengan yang disampaikan Tarigan bahwa berbicara berkaitan dengan penyampaian katakata.

Tarigan menyampaikan bahwa ada tiga tujuan dalam berbicara. Pertama, memberitahukan atau melaporkan (to inform), kedua menjamu dan menghibur (to entertain), dan yang ketiga adalah membujuk, mendesak, mengajak serta meyakinkan (to Persuade). Sesuai dengan tujuan yang disampaikan tersebut, sangat jelas bahwasannya berbicara harus tersampaikan dengan jelas agar tujuan-tujuan tersebut bisa tersampaikan dengan tepat. Dari uraian tersebut, dapat disimpulkan bahwa berbicara merupakan alat berkomunikasi dengan tujuan secara umum memberitahu atau melaporkan, menjamu atau menghibur serta mengajak meyakinkan, merayu atau mendesak.

\section{METODE PENELITIAN}

Penelitian ini merupakan penelitian deskriptif kualitatif. Menurut Donal Ari 2002 penelitian deskriptif kualitatif lebih ditekankan pada data yang bersifat narasi dan observasi dari pada angka. Penelitian ini mendeskripsikan semua yang berhubungan dengan story telling, kemampuan lokal Madura serta kemampuan berbicara siswa SMP kelas VII. Sementara menurut Denzin dan Lincoln dalam Lexy J. Moleong 2006 menyatakan bahwa penelitian kualitatif adalah penelitian yang menggunakan setting yang alami untuk menginterpretasikan sebuah fenomena. Sesuai dengan pernyataan tersebut, peneliti mendeskripsikan peranan story telling berbasis pengetahuan lokal Madura yang dikaitkan dengan fenomena yang biasa dialami dalam berbicara siswa kelas VII SMP.

\section{PEMBAHASAN}

Story telling sebagaimana diungkapkan dengan definisi dan fungsinya merupakan strategi yang diarahkan dalam keterampilan berbicara. Penyusunan kosa kata, ide serta gagasan yang diciptakan siswa sendiri sebagai bahan untuk 
berbicara menjadikan mereka lebih mudah dalam mengungkapkan yang ada dalam pikiran. Bantuan media gambar yang disajikan dalam pengetahuan lokal tidak kalah pentingnya peranannya dalam membantu siswa menggagas ide-idenya. Dengan hal ini siswa mampu menyusun secara berurutan ide serta gagasannya sehingga mereka lebih percaya diri dalam menyampaikannya. Karena sudah melalui proses yang direncanakan yakni menyusun, siswa bisa berbicara dengan lancar. Dari sinilah berbicara akan menghasilkan komunikasi yang sesuai dengan fungsinya.

Penyajian media gambar yang dibatasi dengan pengetahuan lokal Madura juga mempunyai fungsi tersendiri dalam penyusunan ide siswa. Batasan pada gambar-gambar yang disajikan, menjadikan siswa tidak terlalu jauh dalam menggagas idenya. Pengetahuan lokal yang mungkin juga mereka kenal juga memunculkan kosa kata yang sering mereka dapatkan pada kesehariannya. Gambar yang mereka lihatpun juga tidak asing lagi untuk mereka uraikan. Pada akhirnya siswa bisa dengan mudah membuat susunan kosa kata hingga kalimat yang akan mereka gunakan dalam berbicara.

Berbicara yang disusun melalui kota kata, kalimat serta gagasan ide sebelumya menghasilkan susunan pembicaraan yang padan dan setiap siswa bisa melakukannya dibandingkan dengan mereka yang langsung diminta berbicara tanpa media. Pada intinya media gambar berbasis pengetahuan lokal Madura adalah batasan yang disajikan dalam penyusunan ide agar siswa lebih bisa mengornisasikan dengan baik. Story telling sebagai strateginya merupakan cara untuk membuat siswa lebih berani dalam berbicara.

\section{PENUTUP}

Penggunaan metode story telling merupakan kegiatan yang pas digunakan pada siswa SMP sebagai metode dalam kegiatan berbicara. Dengan story telling siswa berusaha mencari kosa kata untuk dipadukan menjadi kalimat. Hal ini tentu saja menuntut usaha siswa untuk bisa berbicara. Pengetahuan lokal Madura yang dikemas kedalam cerita tentang Madura merupakan cara yang bisa digunakan dalam story telling. Dengan menggunakan cerita yang berbasis pengetahuan lokal Madura siswa tidak hilang pengetahuannya sehingga mereka akan terus belajar dan berusaha memahami cerita- cerita yang memang seharusnya mereka tahu. Dengan demikian, mereka akan memadukan pengetahuan mereka dengan kosa kata yang akan mereka rangkai sehingga menjadi kalimat yang bermakna dan menjadi pengetahuan baru. Hal ini yang akan menjadikan bahan mereka untuk bisa berbicara. Dengan paduan kalimat yang mereka rangkai sesuai dengan pengetahuan mereka, mereka akan lebih mudah dalam menyampaikan (berbicara).

\section{REFERENSI}

Arsyad, Azhar. 2017. Media Pembelajaran. Jakarta: Rajawali pers

Ary, Donal (2002). Introduction to research in Education (USA: Wadsworth Group A Division of Thompson Learning Inc)

Fitria,

Nanik.

JURNAL\%20NANIK\%20FITRIA\%20A

NGGRAINI.pdf didownload pada tanggal 2 November 2021 (14.00 WIB)

Hartono.H. (2008). Ilmu Sosial Dasar.Jakarta: Bumi Aksara

Ilham, Muhammad. 2020. Pengantar Keterampilan Berbicara. Pasuruan: Lembaga Academic Subhayni. 2017. Keterampilan Berbicara. Banda Aceh: Syiah Kuala Press

Kadaruddin. 2017. Media dan Multimedia Pembelajaran. Bandung: Rosda

Kamus Besar Bahasa Indonesia. (2001). Pengertian Keterampilan. Jakarta: Balai Pustaka

Musfiqon.1990. Media dan Sumber Pembelajaran. Jakarta: Pustaka Media

Moleong, J. Lexy (2006). Metodologi Penelitian Kualitatif. Bandung: PT. Rosda Karya

Ningsih, Suwarti. 109895-ID-peningkatanketerampilan-berbicara-melal.pdf didownload pada tanggal 2 November 2021.

Slamet, St. Y. (2009). Dasar-dasar keterampilan berbahasa Indonesia. UNS Press.

Sugiyono. (2014). Metode penelitian pendidikan pendekatan kuantitatif, kualitatif, dan R\&D. Alfabeta.

Tarigan, H. G. (2008). Berbicara Sebagai Suatu Keterampilan Berbahasa. Bandung: Angkasa. 